\title{
The anatomical properties of Scabiosa atropurpurea L. (Caprifoliaceae)
}

\author{
Zeynep Büșra Erarslan (1) \& Yeter Yeșil* (1) \\ Department of Pharmaceutical Botany, Faculty of Pharmacy, İstanbul University, 34116, İstanbul, Turkey
}

ORCID IDs of the authors: Z.B.E. 0000-0002-4458-7881, Y.Y. 0000-0001-7541-2569.

Cite this article as: Erarslan ZB, Yeșil Y. The anatomical properties of Scabiosa atropurpurea L. (Caprifoliaceae). Istanbul J Pharm 48 (1): 1-5.

\begin{abstract}
Scabiosa atropurpurea L. (Caprifoliaceae), a medicinal plant traditionally known as "Mor uyuzotu or Seytanotu" in Turkey, has been used for treating acne, bronchitis, cold, and cough. Although phytochemical studies are available, there are no taxonomic studies related to this plant. The aim of this study was to investigate the anatomy of leaf, stem, and root of S. atropurpurea. Detailed photographs of plant parts were taken, and measurements of the leaf, stem, and root were carried out. The cross section of the stem revealed a single-layered epidermis containing one-celled simple eglandular trichomes and rarely onecelled hook-shaped eglandular trichomes. The cortex showed multilayered parenchymatous cells and a single-layered endodermis. The phloem was followed by the cambium, and the xylem was lignified. The pith was made up of parenchymatous cells. The leaves are bifacial and amphistomatic and stomata are mesomorphic in the cross section and also stomata are anomocytic in the surface section.

The cross section of the root showed that the epidermis was replaced with the periderm. Under the phloem, which had few layers, the xylem was composed of tracheary elements surrounded with sclerenchymatous cells.
\end{abstract}

Keywords: Scabiosa atropurpurea, Caprifoliaceae, Seytanotu, plant anatomy, Anatolia.

\section{INTRODUCTION}

The genus Scabiosa L. is a member of the Caprifoliaceae Juss. family and it is represented by ca. 100 species all over the world. Most of Scabiosa species grow in the Mediterranean region (Carlson et al. 2012). This genus is represented by 32 species in Turkey (Göktürk 2012). One of them, S. atropurpurea L., is a biennial or perennial plant which is 20-60 cm in height. This species is separated from other species with its bluish-lilac flower color and the characteristic shape of its fruit. It is native to Turkey and located around roadsides, dry fields, and dunes. The flowering time of this plant is from May to October and it shows a wide distribution in Turkey (Mathew 1972; Ekici 2010; Akalın Uruşak et al. 2013; Köse and Özen 2017).

S. atropurpurea known as "Mor uyuzotu, Şeytan otu" in Turkey (Asal and Yaşarkan 2017; Tuzlacı 2006) is known as "Ambarina" in Northern Peru and "Escabiosa" in Iberian Peninsula (Bussman and Glenn 2010; Bussman et al. 2010). It has been used traditionally in several diseases like acne, bronchitis, cold, cough by means of its analgesic, antipyretic anti- inflammatory and antibacterial activities (Marhuenda-Requena et al. 1987; Saenz-Rodrigues et al. 1987; Bonet et al. 1999; Bussman and Glenn 2010). In Iberian Peninsula, a kind of herbal tea is prepared from its aerial parts and it is used as a veterinary diuretic. In Northern Peru, it is used orally or by inhalation for menstrual regulation (Bonet and Vallès 2007; Bussman and Glenn 2010). In Egypt, it is known as an ornamental plant (Elhawary et al. 2011). Many studies revealed that the main chemical constituents of this species are iridoid 
glucosides, flavonoids and phenolic compounds (Polat et al. 2010; Elhawary et al. 2011).

Anatomical studies were not found in the literature review of the S. atropurpurea. In this study, the stem, leaf and root parts of the taxon were examined and the anatomical structure was revealed for the first time. Moreover, a distribution map of the species was located (Figure 1).

\section{MATERIALS AND METHODS}

The study material, S. atropurpurea was collected from İstanbul, Validebağ Korusu grove on October 2017. The collected specimens were identified by Zeynep Büşra Erarslan and dried specimen of the plant was kept in the Herbarium of Istanbul University Faculty of Pharmacy (ISTE) by herbarium number 115040. Leaves, stems and roots stored in 70\% ethanol for anatomical examination, and then all cross sections and surficial sections were cut by hand with blade. Samples were examined in Sartur reagent. Photographs were taken by Canon Power shot A640 and measurements of stems, leaves and roots were made by program of KAMERAM@.

\section{RESULTS}

\section{Leaf}

From the cross-section of leaf was found to be bifacial, amphistomatic and mesomorphic. The upper and lower epidermises are composed of single-layered, rectangular-rounded cells. Upper epidermal cells have larger sizes than lower epidermal cells. The epidermal cells on both surfaces are surrounded by a thin layer of cutin. On the upper and lower epidermis, there are one-celled eglandular trichomes and multi-celled glandular trichomes. The measurements of the glandular trichomes are $20.65-28.41 \times 30.47-51.49 \mu \mathrm{m}$ and average is -40.55 $\mu \mathrm{m}$. The mesophyll is composed of 3-4 layers of palisade parenchyma cells under the upper epidermis and spongy parenchyma cells with wide intercellular spaces. Leaf thickness is between 314.39 - $356.69 \mu \mathrm{m}$ and average is $335.55 \mu \mathrm{m}$ (Figure $2 a, b, c)$.

In the cross section of the main vein, 1-2 layers of collenchyma are seen under the lower epidermis. There are thin-walled parenchyma cells of different sizes between the collenchyma layer and the vascular bundles. A few druse crystals were seen in this area. Veins are collateral, with the xylem located upper side and phloem located lower side. The leaf main vein thickness is $523.77-686.19 \mu \mathrm{m}$ and average is $601.27 \mu \mathrm{m}$ (Figure 2 $d, e, f)$.

On the surface section, lower epidermal cells seem to be wavier than the upper epidermal cells. On both sides of the lamina there are oval shaped and various sized stomata (Table 1). Stomata anomocytic, 2-3 cells surrounding each stoma which are not recognizably distinct from the remaining cells in the mature epidermis. The stomatal index for the upper surface of the lamina 24.52; the stomatal index for the lower surface is 26.23. The stomatal index ratio was calculated as 0.934 (Figure $3 a, b)$.

\section{Stem}

The outermost part of the herbaceous stem's cross section is composed of epidermal cells with a single layer and the cells are covered by a thin cuticular layer. Width of the epidermal cells is ranging from 16.94 to $18.61 \mu \mathrm{m}$, length is ranging from $14.68 \mu \mathrm{m}$ to $19.10 \mu \mathrm{m}$. One-celled simple eglandular trichomes and rarely one-celled hook-shaped eglandular trichomes are seen on the epidermis. Just below this layer, there are varying sizes of multilayered parenchymatous cells which are forming the cortex part of the stem. A single layered en-

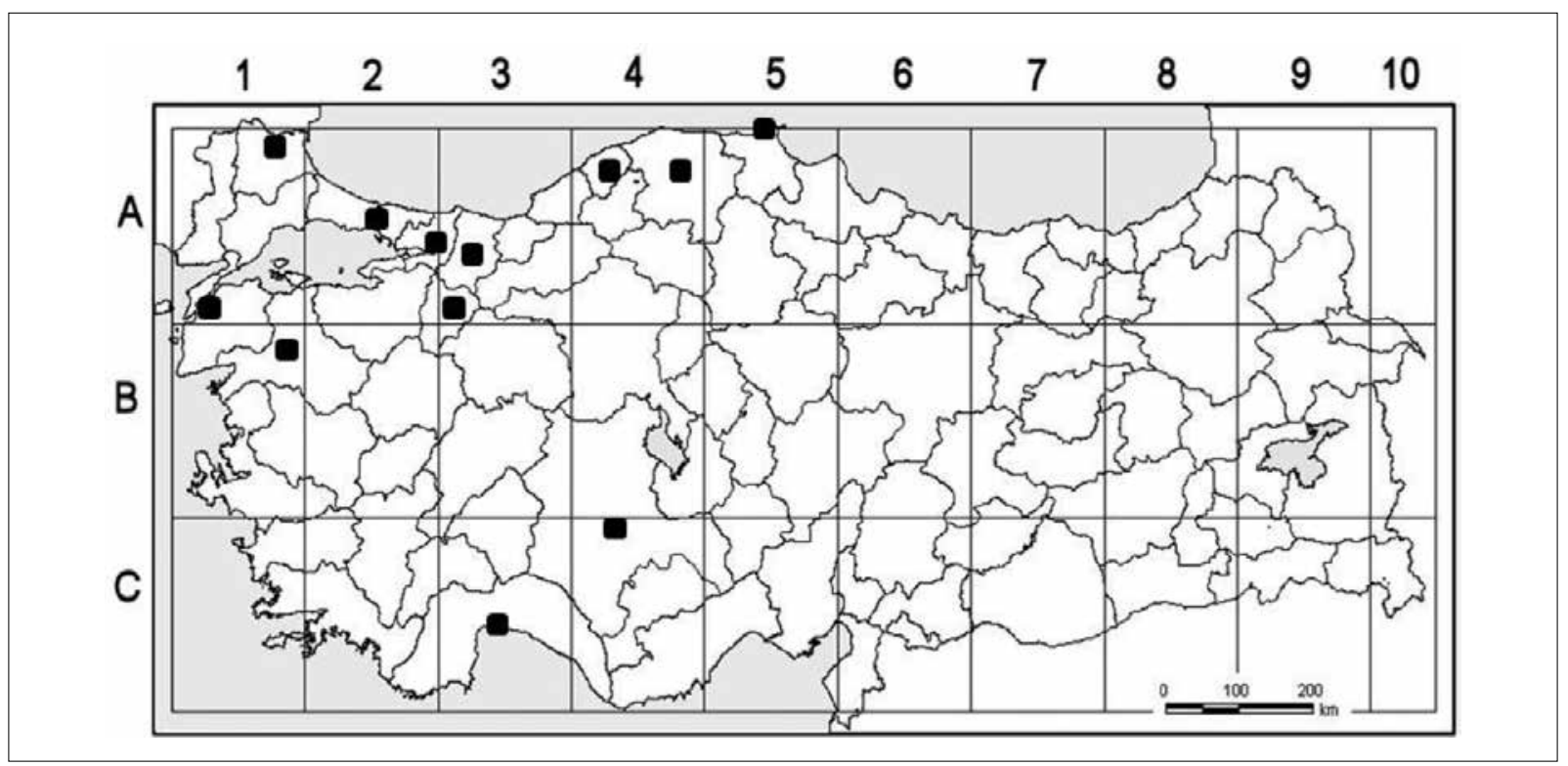

Figure 1. Distribution map of S. atropurpurea L. in Turkey. 


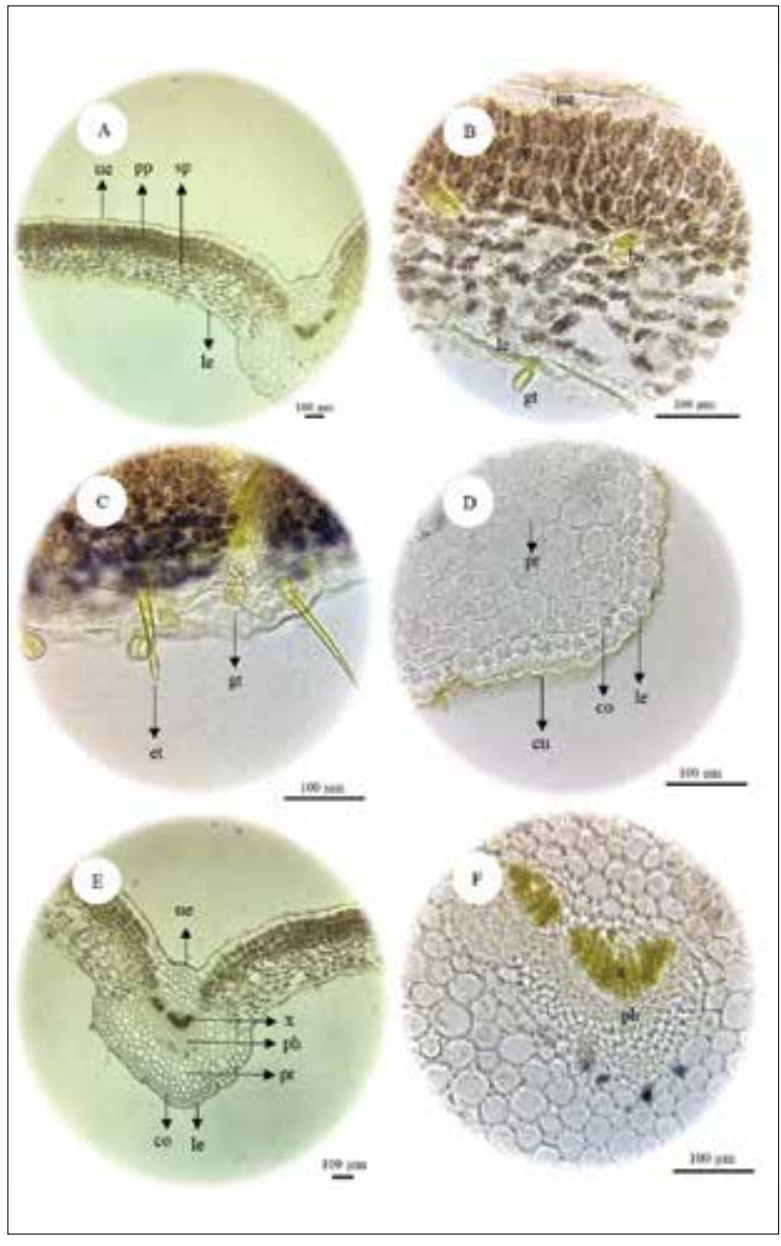

Figure 2. a-f. (a) The cross sections of leaves of S. atropurpurea, (b) intervascular part of leaf (mesophyll), (c) trichomes, (d), (e) the main vein, (f) vascular bundle; bs bundle sheath, co collenchyma, cu cuticula, et eglandular trichome, gt glandular trichome, le lower epidermis, ph phloem, pp palisade parenchyma, pr parenchyma, st stomata, sp spongy parenchyma, ue upper epidermis $\mathrm{x}$ xylem.

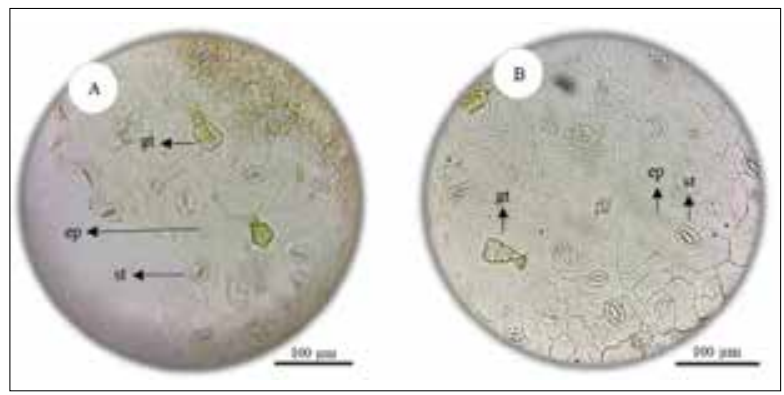

Figure 3. a,b. The surface sections of leaves of S. atropurpurea; (a) upper surface of leaf, (b) lower surface of leaf; ep epidermis, gt glandular trichome, st stomata.

dodermis is located under parenchyma cells. The phloem is followed by cambium. The xylem lignified and forms a wider layer than phloem. The pith comprises of large parenchymatous cells which have got starch grains and thicken on the walls as they approach the xylem layer. Parenchyma cells vary in diameter (Table 1, Figure 4 a-d).

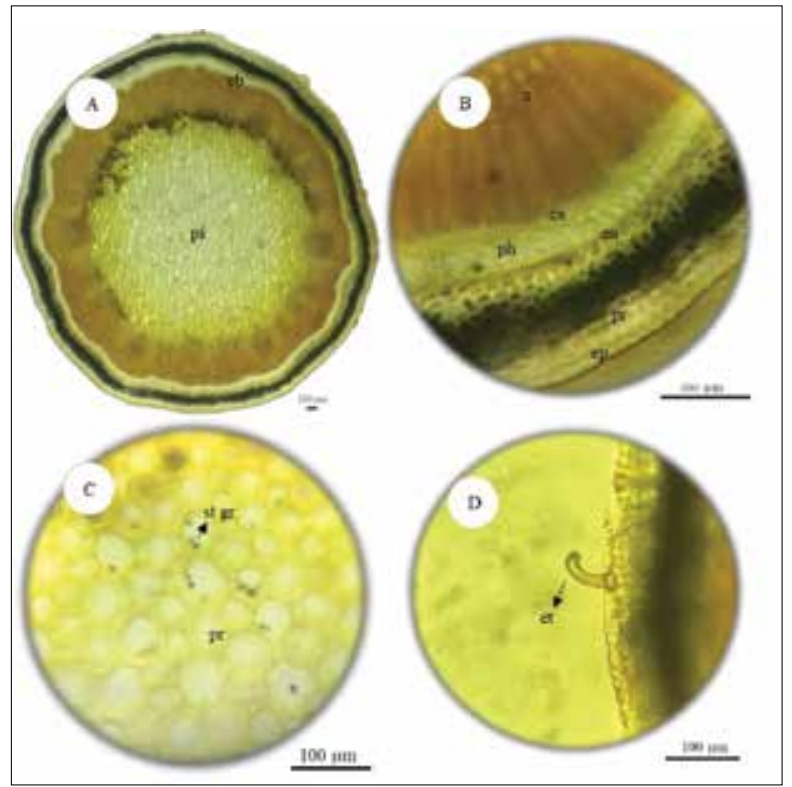

Figure 4. a-d. The cross sections of stem of $S$. atropurpurea; (a) general view, (b) cortex and vascular bundles, (c) pith, (d) trichome; ep epidermis, en endodermis, pr parenchyma, et eglandular trichome, ph phloem, pi pith, st gr starch grain, $x$ xylem, vb vascular bundle.

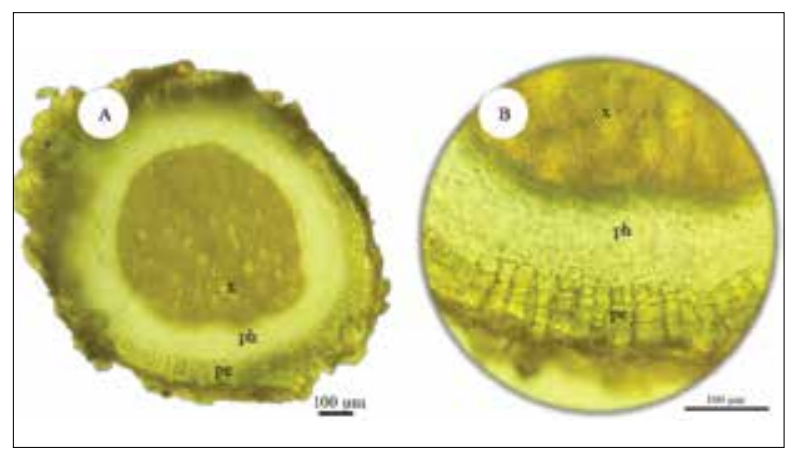

Figure 5. a,b. The cross section of root of $S$. atropurpurea; (a) general view, (b) cortex and vascular bundles; pe periderm, ph phloem, x xylem.

\section{Root}

On the cross section, the cells of epidermis are replaced by 2-3 layers of periderm. Endodermis is not seen. Under a few layered phloem, xylem is composed of tracheary elements with surrounded by sclerenchymatous cells in root. Diameters of trachea cells are 13.84 - $34.75 \mu \mathrm{m}$ (Table 1, Figure $5 \mathrm{a}, \mathrm{b}$ ).

\section{DISCUSSION}

The stem, leaf and root anatomy of S. atropurpurea were examined and the results were compared with literatures in this study.

The anatomical study's with Scabiosa rotata M.Bieb, it is stated that the eglandular trichomes are present in the stem and leaf, and also a small amount of glandular trichomes are present in the leaf. In addition, it was observed that S. atropurpurea 
Table 1. Anatomical measurements of S. atropurpurea.

\begin{tabular}{|c|c|c|c|c|c|c|c|c|}
\hline & \multicolumn{4}{|c|}{ Width $(\mu \mathrm{m})$} & \multicolumn{4}{|c|}{ Length ( $\mu \mathrm{m})$} \\
\hline & \multicolumn{2}{|c|}{ Min. - Max. } & \multicolumn{2}{|c|}{ Avr. $\pm S d$} & \multicolumn{2}{|c|}{ Min. - Max. } & \multicolumn{2}{|c|}{ Avr. $\pm S d$} \\
\hline & & & & & & & \multicolumn{2}{|c|}{ Stem } \\
\hline Epidermis cell & 16.94 & 18.61 & 17.70 & 0.74 & 14.68 & 19.10 & 17.21 & 1.84 \\
\hline Pith cell (diameter) & 30.34 & 76.03 & 51.28 & 17.83 & & & & \\
\hline Trachea (diameter) & 8.85 & 18.33 & 14.67 & 3.75 & & & & \\
\hline Endodermis cell & 6.81 & 13.04 & 10.67 & 2.78 & 18.74 & 39.37 & 25.49 & 8.31 \\
\hline \multicolumn{9}{|l|}{ Leaf } \\
\hline Upper epidermis cell & 8.78 & 26.01 & 18.01 & 7.37 & 24.16 & 42.42 & 34.10 & 8.44 \\
\hline Upper stomata & 18.38 & 20.31 & 19.05 & 0.79 & 21.79 & 34.53 & 28.35 & 4.52 \\
\hline Trachea (diameter) & 4.66 & 11.24 & 7.03 & 2.08 & & & & \\
\hline Lower stomata & 12.07 & 17.10 & 14.17 & 2.15 & 18.48 & 26.52 & 22.74 & 3.10 \\
\hline Lower epidermis cell & 7.73 & 14.22 & 11.62 & 2.97 & 26.23 & 16.94 & 33.17 & 9.33 \\
\hline \multicolumn{9}{|l|}{ Root } \\
\hline Periderm cell & 9.54 & 15.26 & 13.12 & 2.41 & 16.17 & 22.80 & 20.46 & 2.14 \\
\hline Trachea (diameter) & 13.84 & 34.75 & 22.01 & 7.71 & & & & \\
\hline
\end{tabular}

leaves and stem have eglandular trichomes (Panayir and Baykal 1997). Additionally, in an anatomical study with S. hispidula Boiss., it is stated that glandular trichomes are present in the stem and especially in the leaf. Therefore, S. atropurpurea is similar to $S$. hispidula with the appearance of glandular trichome in the leaf (Akyol et al. 2016).

It is also stated that all of these features in the cross sections of S. rotata and S. hispidula, are found in the members of the subfamily (Panayır and Baykal 1997; Akyol et al. 2016). It is reported that S. hispidula has hydathode. On the other hand, hydathode was not observed in S. atropurpurea anatomy.

In the other species of plant, clustered crystals (Akyol et al. 2016) or druse and salt crystal sands (Panayır and Baykal 1997) are found in the leaf and root anatomy of the species. Only druse crystals were observed in the leaf anatomy of S. atropurpurea species.

\section{REFERENCES}

- $\quad$ Akalın Uruşak E, Özhatay F. N., Güler N., Ersoy H., Başak N., Yeşil Y., Oral D., Demirci S (2013). The flora of Yıldız Mountains (Kırklareli) Biosphere Project area. Turk J B 37: 225-269.

- Akyol Y, Kocabaş O, Kayacan E, Minareci E, Özdemir C (2016). Scabiosa hispidula Boiss. (Caprifoliaceae) Türüne Ait Anatomik Bir Çalışma. Nevşehir Bilim ve Teknoloji Dergisi 5: 10- 15.

- $\quad$ Asal D and Yaşarkan O (2017). "Türkiye Bitkileri Listesi (Damarlı Bitkiler)"nde Mükerrer Olan 171 Takson Iç̧in Yeni Bilimsel Türkçe Adlar. Bağbahçe Bilim Dergisi 4: 1-7.

- Bonet MA and Vallès J (2007). Ethnobotany of montseny biosphere reserve (Catalonia, Iberian Peninsula): Plants used in veterinary medicine. J Ethnopharmaco/ 110: 130-147.
Bonet MA, Prada M, Selga A, Vallès J (1999). Studies on pharmaceutical ethnobotany in the regions of L'Alt Empordà and Les Guilleries (Catalonia, Iberian Peninsula). J Ethnopharmacol 68 145-168.

- Bussman RW and Glenn A (2010). Medicinal plants used in Northern Peru for reproductive problems and female health. $J$ Ethnobiol Ethnomed 6: 30.

- Bussman RW, Glenn A, Meyer K, Kuhlman A and Townesmith A (2010). Herbal mixtures in traditional medicine in Northern Peru, J Ethnobiol Ethnomed 6: 10.

- Carlson SE, Linder HP, Donoghue MJ (2012). The historical biogeography of Scabiosa (Dipsacaceae): implications for Old World plant disjunctions. J Biogeogr 39: 1086-1100.

- Mathews V.A (1972). Scabiosa L. in Davis PH (Ed). The Flora of Turkey and the East Aegean Islands. Vol. 1-9, Edinburgh University Press, Edinburgh.

- Elhawary SS, Eltantawy ME, Sleem AA, Abdallah HM, Mohamed NM (2011). Investigation of Phenolic Content and Biological Activities of Scabiosa atropurpurea L. World App/ Sci J 15: 311-317.

- $\quad$ Ekici B (2010). Bartın Kenti Ve Yakın Çevresinde Yetişen Bazı Doğal Bitkilerin Kentsel Mekânlarda Kullanım Olanakları. SDÜ Orman Fakültesi Dergisi A2: 110-126.

- Göktürk RS. (2012). Scabiosa L. in Güner A, Aslan S, Ekim T, Vural M \& Babaç MT (eds.). Türkiye Bitkileri Listesi (Damarlı Bitkiler). Nezahat Gökyiğit Botanik Bahçesi ve Flora Araştırmaları Derneği Yayını. İstanbul.

- $\quad$ Köse M, Özen F. (2017). Hereke Florası. SAUJS, 21 (6), 1165-1175.

- Marhuenda-Requena E, Saenz-Rodriguez MT, Garcia-Gimenez MD (1987). A contribution to the pharmacodynamic study of Scabiosa atropurpurea L.I. Analgesic and antipyretic activity. Plant Med Phytoter 21: 47-55.

Panayır T, Baykal T (1997). Scabiosa rotata BIEB. (Dipsacaceae) Üzerinde Morfolojik ve Anatomik Araştırmalar. J Fac Pharm Ankara 26: 22-35. 
- Polat E, Alankuş Çalışkan O, Karayıldıım T, Bedir E (2010). Iridoids from Scabiosa atropurpurea L. subsp. maritima Arc. (L.). Biochem Syst Ecol 38: 253-255.

- Saenz-Rodrigues MT, Garcia-Gimenez MD, MarhuendaRequena E (1987). A contribution to the pharmacody- namic study of Scabiosa atropurpurea L. II. Antiinflammatory and antibacterial activity. Plant Med Phytoter 21: 203-208.

Tuzlacı E (2006). Türkiye Bitkileri Sözlüğü. Alfa Yayınları, Istanbul. 